\title{
Seabird bycatch in the Argentinean demersal longline fishery, 2001-2010
}

\author{
Marco Favero ${ }^{1, *}$, Gabriel Blanco ${ }^{2}$, Sofía Copello ${ }^{1}$ Juan Pablo Seco Pon ${ }^{1}$, \\ Carla Patterlini ${ }^{1}$, Rocío Mariano-Jelicich ${ }^{1}$, Germán García ${ }^{1}$, María Paula Berón ${ }^{1}$ \\ ${ }^{1}$ Instituto de Investigaciones Marinas y Costeras (IIMyC), Consejo Nacional de Investigaciones \\ Científicas y Técnicas - Universidad Nacional de Mar del Plata, Funes 3250 (B7602AYJ), Mar del Plata, Argentina \\ ${ }^{2}$ Instituto Nacional de Investigación y Desarrollo Pesquero, Programa Observadores a Bordo y Muestreo de Desembarco, \\ Paseo Victoria Ocampo N $^{\circ} 1$ (B7602HSA), Mar del Plata, Argentina
}

ABSTRACT: Seabird mortality associated with fisheries is one of the major threats leading to population decreases of certain species, particularly albatrosses and petrels. The present study was conducted to (1) analyze seabird bycatch in the Argentinean demersal longline fishery during the decade 2001 to 2010, (2) provide a baseline of the levels of incidental mortality prior to the implementation of the National Plan of Action-Seabirds, and (3) characterize in space and time the occurrence and intensity of seabird mortality. Fishing effort decreased from some 30 million to 5 million hooks set per year, and the overall bycatch rate for the whole period was 0.033 (0.019 SE) birds per 1000 hooks. The estimated total mortality for the $10 \mathrm{yr}$ period was $7470 \pm 2449$ seabirds, the majority being black-browed albatrosses and white-chinned petrels. Seabird mortalities decreased by 1 order of magnitude towards the end of the decade, not due to lower bycatch rates but to a drop in the number of hooks set per year. The progress achieved so far in Argentina is important, but if seabird bycatch is to be reduced to negligible levels, it is imperative that the National Plan of Action-Seabirds is effectively implemented and that the longline fishery comply with the conservation measure calling for the use of mitigation methods that came into effect in 2010. Other management-related actions, such as the increase of capacities within the National Observer Program and the refinement of seabird sampling protocols, will have an effect not only in the longline but also in the large trawl fishery, where seabird bycatch has also been documented.

KEY WORDS: Seabird bycatch · Argentina Demersal longline fishery $\cdot$ Albatross conservation

Resale or republication not permitted without written consent of the publisher

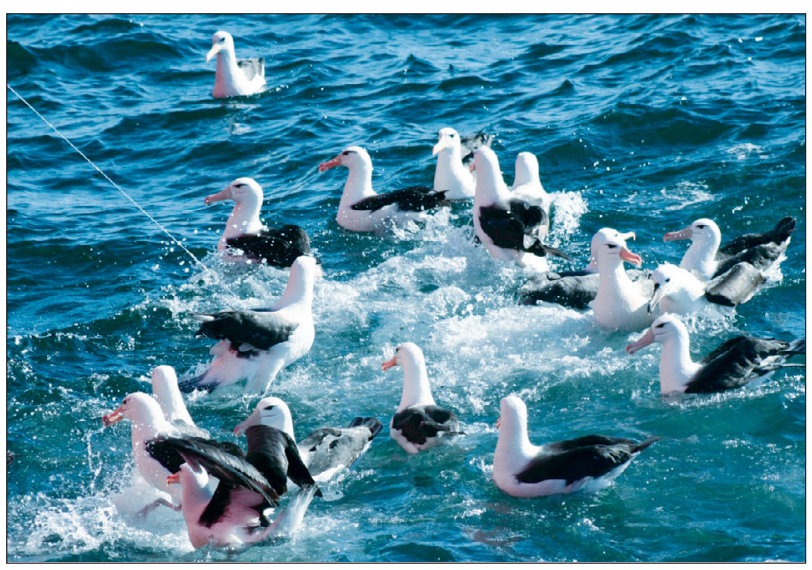

The black-browed albatross is the most common albatross killed in demersal longline fisheries in the SW Atlantic. Photo: Juan Pablo Seco Pon

\section{INTRODUCTION}

The incidental mortality of seabirds associated with fisheries was raised more than 2 decades ago as an important conservation issue affecting globally threatened species (Weimerskirch \& Jouventin 1987, Brothers 1991). It is still believed to be one of the most important threats leading to the population decrease of various species, particularly those showing low productivity and delayed maturity, such as albatrosses and petrels (Arnold et al. 2006, Gales 2008, Rivalan et al. 2010, Croxall et al. 2012). Apart from the detrimental effect of demersal and pelagic longline fisheries, the threat posed to seabirds by trawl fisheries has also recently been recognized 
(Weimerskirch et al. 2000, Sullivan et al. 2006, Watkins et al. 2008, Favero et al. 2011). A review of seabird bycatch across all major longline fisheries highlighted the need to update long-term information on seabird bycatch in order to understand the problem and identify areas of highest risk (Anderson et al. 2011). Despite the growing knowledge and progress made on this conservation issue in both demersal and pelagic longline fisheries, global bycatch remains a major threat to be addressed. Complex scenarios allied with the imperative need to develop strategies at an international scale and the slow institutional reaction in national and international management agencies and organizations have precluded or slowed the development and implementation of conservation measures (Robertson \& Gales 1998, Melvin \& Parrish 2001).

National and international efforts have allowed some progress in addressing incidental mortality of the most fragile groups, such as albatrosses and petrels. Recent reviews indicate that 17 out of the 22 albatross species are currently threatened with extinction, some of listed as Endangered or Critically Endangered (IUCN 2011). Further, both due to threats fared both at sea and on land, all albatross species and 8 petrel species have been listed under Annex 1 of the Agreement on the Conservation of Albatrosses and Petrels (ACAP 2012). In recent years, and as a result of the FAO International/ National Plan of Action-Seabirds (IPOA/NPOASeabirds; FAO 2008) and subsequent international initiatives, a number of nations have developed national plans of action on seabirds (hereinafter NPOA-S), or equivalent programs, to minimize the detrimental effects of fishing activities on seabirds. However, the elaboration of such NPOA-S must be implemented by concrete and targeted actions to minimize at-sea threats to seabirds and improve their conservation status.

The Patagonian Shelf and its shelf break is a very important foraging area for seabirds, among other local and non-resident marine top predators (Croxall \& Wood 2002, Favero \& Silva 2005, Phillips et al. 2006, Arata et al. 2009). These waters are used as foraging grounds not only for species breeding in the area, such as wandering albatross Diomedea exulans and black-browed albatross Thalassarche melanophrys; northern giant petrel Macronectes halli, southern giant petrel M. giganteus, and whitechinned petrel Procellaria aequinoctialis, but also for those breeding in the southeast Atlantic such as the Tristan albatross D. dabbenena, and in the South Pacific, such as the southern royal albatross D. epo- mophora and northern royal albatross D. sanfordi. Argentinean waters cover a substantial portion of the above-mentioned area, where the distribution of albatrosses and petrels overlap with large trawl, jigging, and longline fishing operations. The growth of these fisheries in Argentina during the 1980s caused considerable concern among conservationists with regard to the possible effects on fish stocks and top predators (Bastida et al. 2005). In particular, the demersal longline fisheries started in the late 1980s and reached their peak in fishing effort during the mid1990s, when some 12 longliners were in operation, chiefly targeting Patagonian toothfish Dissostichus eleginoides, kingclip Genypterus blacodes, and yellownose skate Dipturus chilensis, using either Spanish (double line) or Mustad (autoline) gears. By the late 1990s, the number of demersal longliners had declined to the current level of 3 to 4 vessels, some of which have converted from Spanish longline to autoline gear and throughout the year alternate the use of the latter with the use of pots (targeting kingclip). These changes in the fishery came along with: (1) the adoption of Resolution 08/08 by the Federal Fisheries Council for the mandatory use of mitigation measures in demersal longline vessels following in principle the ACAP advice for the use in combination of night setting, line weighting, or bird scaring line (ACAP 2011), further enforced in 2010 by the UnderSecretariat of Fisheries; and (2) the adoption by the Federal Fishery Council of Argentina in 2010 of the Argentinean NPOA-S (Resolution CFP 15/2010; Consejo Federal Pesquero 2010), calling for actions to address at-sea conservation issues in all fisheries.

Although previous studies have provided estimates of the level of seabird mortality in the Argentinean longline fleet and analyzed the effect of operational and environmental factors on bycatch (see Favero et al. 2003, Gandini \& Frere 2006, Gómez Laich et al. 2006, Gómez Laich \& Favero 2007, among others), neither long-term databases nor variability within the whole fleet have been examined. The present study was conducted as part of a program jointly commissioned to the National Fisheries Institute (INIDEP) and the National Research Council of Argentina (CONICET) with the goals of (1) analyzing the extant database from the National Observer Program on seabird bycatch in the Argentinean demersal longline fishery during the period 2001 to 2010, (2) providing a baseline level of incidental mortality prior to the adoption of the NPOA-S in 2010, and (3) characterizing in space and time the occurrence and intensity of seabird mortality associated with longliners. 


\section{MATERIALS AND METHODS}

\section{Characteristics of the fishery under study}

Argentinean longliners are roughly between 150 and 180 feet ( 45 to $55 \mathrm{~m}$ ) long, with 1000 to $2200 \mathrm{HP}$, and have a carrying capacity of 180 to $800 \mathrm{~m}^{3}$. Vessels are equipped with fish meal plants, and discharge waste without any processing (generally head, tail, and guts) from commercially valuable fish species. Although the patterns in the fishing operation might change slightly from year to year, each vessel commonly made some 5 to 6 trips $\mathrm{yr}^{-1}$, with each trip lasting $49 \mathrm{~d}$ on average.

Between 2001 and 2010, longline fisheries in Argentina decreased both in terms of fleet size and fishing effort (i.e. numbers of hooks set). From some 12 vessels (and ca. 30 million hooks set per year) operating in the Argentinean Economic Exclusive Zone during the late 1990s, approximately 8 longliners fished at the beginning of the decade (with a fishing effort of ca. 20 to 28 million hooks), and only 4 (ca. 5 to 6 million hooks set per year) remained at the end of the study period. For the purpose of this study, the longline fishery was divided into 3 categories (hereinafter fleets) according to the fishing gear used, the target species, and the area of operation as follows: (1) vessels using exclusively an autoline (Mustad) system and primarily targeting Patagonian toothfish in southern Argentina in the vicinity of Burwood Bank $\left(54.25^{\circ} \mathrm{S}, 59.00^{\circ} \mathrm{W}\right)$ and along the continental slope (hereinafter Toothfish fleet), (2) vessels using a Spanish or autoline system (some of which later changed to 'cachaloteras'; see explanation below), targeting both Patagonian toothfish and kingclip, and operating mostly on the central Patagonian shelf and shelf break (hereinafter Kingclip-Toothfish fleet), and (3) vessels using a Spanish system only and targeting yellownose skate on the northern Patagonian shelf (hereinafter Skate fleet) (Fig. 1). These fleets were analyzed separately because vessels using different gear configuration and materials (i.e. Spanish, autoline, 'Cachaloteras'), as well as operating in different areas, may show dissimilarities in bycatch levels and species captured (Gómez Laich et al. 2006, Gómez Laich \& Favero 2007, Seco Pon et al. 2007). Further, these 3 fleets have evolved in different ways through the analyzed period, partly changing fishing gear or ceasing activities towards the end of the decade.

The Spanish system consists of 2 lines set in parallel-a heavy hauling line and a light-weight hook line (or mainline). Numerous secondary lines or branches join the hauling line to the hook line at appropriate intervals. The hauling line is stored on vessels as a continuous length of line, and the hook line is stored in separate plastic baskets (Robertson 2000). The gear of the Spanish system comprises lines rigged with hooks of $7 \mathrm{~cm}$ of mean total length and $3 \mathrm{~cm}$ of mean gape on $40 \mathrm{~cm}$ snoods at $120 \mathrm{~cm}$ spacing. The Argentine shortfin squid Illex argentinus and jumbo squid Dosidicus gigas are generally used as bait, and hooks are manually baited. The autoline system consists of a single line that is kept in sections (magazines) and rigged to carry swivels with hooks of $8 \mathrm{~cm}$ of mean total length and ca. $4 \mathrm{~cm}$ of mean gape on $45 \mathrm{~cm}$ snoods at $120 \mathrm{~cm}$ swivels spacing. Each magazine is up to ca. $50 \mathrm{~km}$ in length and holds approximately 3000 hooks on average. The Argentine shortfin squid and sardines Sardina spp. are used as bait. Both the Spanish and autoline systems deploy longlines with weights attached at regular intervals to make them sink and remain close to the bottom. Part of the Kingclip-Toothfish fleet also used a gear with buoys alternately attached to the mainline, so weights prevents the line drifting from its position on the seabed while buoys lifts the gear off the seabed, enabling fishing to occur at different depths (Seco Pon et al. 2007). Towards the end of the decade, a portion of this fleet changed to 'cachaloteras', also known as the umbrella-and-stones system or Chilean mixed system, consisting of a coneshaped umbrella-like net sleeve protecting the hooked fish from marine mammal depredation during hauling. Although it was not originally designed to address seabird bycatch, given its configuration and the associated weighting regime, this method has proven to be effective in reducing seabird mortality, mostly due to improved sinking rates (Moreno et al. 2008, Goetz et al. 2011).

\section{Data collection and analysis}

Data were collected between 2001 and 2010 by observers from the National Observers Program (INIDEP, National Fisheries Institute, Argentina) on board demersal longliners. Over 100 fishing trips and 159 million hooks set were analyzed. Since 2001, observers were gradually trained by personnel from INIDEP, National Universities, and non-governmental organizations (NGOs) in the collection of data on bycatch of seabirds and other top predators. Estimations of seabird mortality were based on dead birds hauled aboard and identified to species level as part of the minimum standard protocols currently in place in the 

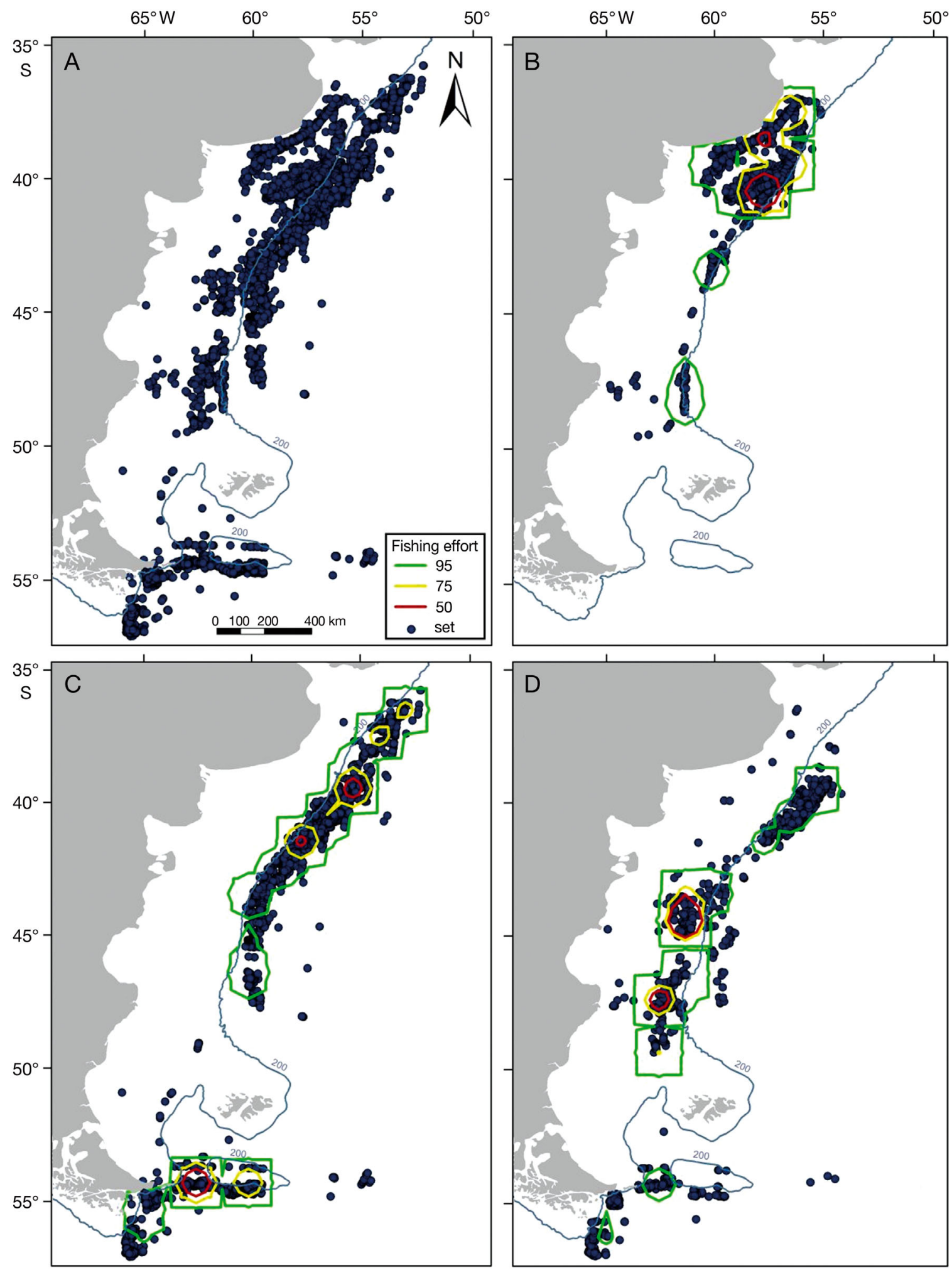

Fig. 1. (A) Distribution of total fishing effort for demersal longline fishery from 2001 to 2010, and detailed by fishery fleet as follows: (B) Skate fleet, longliners targeting skate Dipturus chilensis with the Spanish system; (C) Toothfish fleet, vessels targeting Patagonian toothfish Dissostichus eleginoides with autoline gear; and (D) Kingclip-Toothfish fleet, longliners targeting Patagonian toothfish and kingclip Genypterus blacodes with Spanish or autoline systems. Points show the actual locations of line settings, and lines denote a kernel analysis $(50 \%, 75 \%$, and $95 \%$ contour plots) for distribution of fishing effort 
longline fleet. Dead birds were assumed to have interacted with the fishing gear and been hooked during the setting operation. Protocols did not include the observation of seabird interactions during setting operations; hence there was no assessment of hidden mortality (i.e. hooked birds being lost before the line was retrieved; see Brothers et al. 2010). Observers were not dedicated full-time to the collection of information on seabird bycatch since they were tasked to work in the factory as well. For this reason, and given that the number of seabird hooks observed to determine whether or not they resulted in seabird bycatch was not systematically quantified in the database, seabird bycatch per unit effort was estimated assuming a 'seabird observed' coverage (i.e. proportion of hooks observed out of the total number of hooks set) equal to $60 \%$ of the total number of hooks set in trips with an observer aboard. Part of the dataset from 2001 was already presented in the only report of seabird bycatch levels in the demersal longliners in Argentina (see Favero et al. 2003), and part of datasets between 2001 and 2003 were used to analyze the effect of environmental and operational variability on the bycatch rates of black-browed albatrosses and white-chinned petrels (see Gómez Laich et al. 2006, Gómez Laich \& Favero 2007).

Seabird bycatch per unit effort was quantified as the number of birds killed every 1000 hooks set. Total seabird mortalities were estimated considering the total fishing effort, the proportion of the effective number of hooks observed, and the number of observed fishing trips out of the total number of trips in a given year (Klaer \& Polacheck 1997). Methods assuming the log-normal distribution of non-zero observations (e.g. Pennington 1983) were not used, given their limited robustness, particularly for small sample sizes (Myers \& Pepin 1990). On the basis of the number of observed cruises and hooks set per year, as well as the spatio-temporal observer coverage, the reliability of bycatch estimates were a priori classified as poor, medium, or good, following criteria in Anderson et al. (2011).

The effect of fleet and seasonality on the occurrence of seabird bycatch (and specifically for blackbrowed albatross and white-chinned petrel) was analyzed by developing generalized linear mixed models (GLMMs) with binomial error structure (2 possible values for the response variable: 0 for no bycatch and 1 for bycatch) and log-link function (Crawley 2007). Vessel and trip identities were included in all models as a random effect assuming the non-independence between sets within the same fishing trip and vessel. The effect of the same predic- tor variables on bycatch rates was analyzed by developing GLMMs with binomial error structure and loglink function (Pinheiro \& Bates 2000, Crawley 2007). Considering the non-independence between sets performed in a given trip, the trip ID was included in all models as a random effect. When overdispersion was detected, the standard errors were corrected using a quasi-GLMM model where the variance is given by $\varphi \times \mu$, with $\varphi$ as dispersion parameter and $\mu$ as mean (Zuur et al. 2009). Fleets (Toothfish, Kingclip-Toothfish, and Skate) and quarters (e.g. Q1 = January to March) were included in all models as categorical variables. In both analyses (bycatch occurrence and rate), the modeling was performed using a subset of data comprising the period 2006 to 2010. This was decided for 2 reasons: (1) because data reliability for that period was higher than early years in the decade, and (2) in order to provide a picture of the dynamics of the whole fishery closer to the present time. All models were carried out using $\mathrm{R}$ software, version 2.13.1 (R Development Core Team 2011). The level of significance in all tests was set to $\mathrm{p} \leq 0.05$. Range (95\%), focal $(75 \%)$, and core $(50 \%)$ areas for the distribution of fishing effort and seabird mortalities were modeled by developing kernel plots weighted by the number of hooks set in a given setting (Worton 1989, Louzao et al. 2011).

\section{RESULTS}

The overall bycatch rate for the period 2001 to 2010 was $0.033 \pm 0.019$ birds (all values are mean $\pm \mathrm{SE}$ ) per 1000 hooks (a total of 1194 birds captured over 36.6 million hooks observed). The list of seabirds recorded in the bycatch was dominated by the black-browed albatross (overall rate: $0.010 \pm 0.001$ birds per 1000 hooks) and the white-chinned petrel $(0.009 \pm 0.001$ birds per 1000 hooks). Other procellariiform species in the bycatch were the great shearwater Puffinus gravis and giant petrels (northern giant petrels Macronectes halli and southern giant petrels M. giganteus pooled) (Table 1). Cumulative annual mortalities for the decade were estimated as $7470 \pm 2449$ seabirds, of which $3122 \pm 336$ were black-browed albatrosses and $2180 \pm 233$ were white-chinned petrels.

As a consequence of the variation in the size of the fishery and fishing effort, annual fish catches varied substantially over the decade. From 2001 to 2003, the total catches ranged between ca. 7000 and $9000 \mathrm{t}$; from 2004 to 2008, catches were between 3000 and $3500 \mathrm{t}$; and from 2009 to 2010, catches were under 2000 t, with no vessels targeting yellownose skate in 
Table 1. Seabird species reported in the bycatch of the Argentinean demersal longline fleet and observed numbers killed from 2001 to 2010. Bycatch rates are number of birds bycaught per 1000 hooks set. TF: autoline targeting toothfish Dissostichus eleginoides, KTF: Spanish autoline systems targeting toothfish and kingclip Genypterus blacodes, SF: Spanish system targeting skate Dipturus chilensis. IUCN concentration status in parentheses-LC: Least Concern, NT: Near Threatened, VU: Vulnerable, EN: Endangered (IUCN 2011)

\begin{tabular}{|c|c|c|c|c|}
\hline \multirow[t]{2}{*}{ Species } & \multicolumn{4}{|c|}{ Mortalities observed (bycatch rate) } \\
\hline & TF & KTF & SF & Total \\
\hline $\begin{array}{l}\text { Wandering albatross } \\
\text { Diomedea exulans (VU) }\end{array}$ & $\begin{array}{c}1 \\
(0.000)\end{array}$ & $\begin{array}{c}3 \\
(0.000)\end{array}$ & $\begin{array}{c}0 \\
(0)\end{array}$ & $\begin{array}{c}4 \\
(0.000)\end{array}$ \\
\hline $\begin{array}{l}\text { Black-browed albatross } \\
\text { Thalassarche melanophrys (EN) }\end{array}$ & $\begin{array}{c}46 \\
(0.004)\end{array}$ & $\begin{array}{c}247 \\
(0.029)\end{array}$ & $\begin{array}{c}84 \\
(0.005)\end{array}$ & $\begin{array}{c}377 \\
(0.010)\end{array}$ \\
\hline $\begin{array}{l}\text { White-chinned petrel } \\
\text { Procellaria aequinoctialis (VU) }\end{array}$ & $\begin{array}{c}66 \\
(0.006)\end{array}$ & $\begin{array}{c}311 \\
(0.036)\end{array}$ & $\begin{array}{c}71 \\
(0.004)\end{array}$ & $\begin{array}{c}448 \\
(0.012)\end{array}$ \\
\hline $\begin{array}{l}\text { Giant petrel } \\
\text { Macronectes spp. (LC) }\end{array}$ & $\begin{array}{c}7 \\
(0.001)\end{array}$ & $\begin{array}{c}20 \\
(0.002)\end{array}$ & $\begin{array}{c}15 \\
(0.001)\end{array}$ & $\begin{array}{c}42 \\
(0.001)\end{array}$ \\
\hline $\begin{array}{l}\text { Cape petrel } \\
\text { Daption capense (LC) }\end{array}$ & $\begin{array}{c}1 \\
(0.000)\end{array}$ & $\begin{array}{c}3 \\
(0.000)\end{array}$ & $\begin{array}{c}0 \\
(0)\end{array}$ & $\begin{array}{c}4 \\
(0.000)\end{array}$ \\
\hline $\begin{array}{l}\text { Great shearwater } \\
\text { Puffinus gravis (LC) }\end{array}$ & $\begin{array}{c}0 \\
(0)\end{array}$ & $\begin{array}{c}10 \\
(0.001)\end{array}$ & $\begin{array}{c}98 \\
(0.006)\end{array}$ & $\begin{array}{c}108 \\
(0.003)\end{array}$ \\
\hline $\begin{array}{l}\text { Sooty shearwater } \\
\text { Puffinus griseus (NT) }\end{array}$ & $\begin{array}{c}2 \\
(0.000)\end{array}$ & $\begin{array}{c}0 \\
(0)\end{array}$ & $\begin{array}{c}0 \\
(0)\end{array}$ & $\begin{array}{c}2 \\
(0.000)\end{array}$ \\
\hline $\begin{array}{l}\text { Unidentified shearwater } \\
\text { Puffinus spp. }\end{array}$ & $\begin{array}{c}0 \\
(0)\end{array}$ & $\begin{array}{c}0 \\
(0)\end{array}$ & $\begin{array}{c}2 \\
(0.000)\end{array}$ & $\begin{array}{c}2 \\
(0.000)\end{array}$ \\
\hline $\begin{array}{l}\text { Kelp gull } \\
\text { Larus dominicanus (LC) }\end{array}$ & $\begin{array}{c}0 \\
(0)\end{array}$ & $\begin{array}{c}104 \\
(0.012)\end{array}$ & $\begin{array}{c}0 \\
(0)\end{array}$ & $\begin{array}{c}104 \\
(0.003)\end{array}$ \\
\hline $\begin{array}{l}\text { Magellanic penguin } \\
\text { Spheniscus magellanicus (NT) }\end{array}$ & $\begin{array}{c}1 \\
(0.000)\end{array}$ & $\begin{array}{c}2 \\
(0.000)\end{array}$ & $\begin{array}{c}0 \\
(0)\end{array}$ & $\begin{array}{c}3 \\
(0.000)\end{array}$ \\
\hline Unidentified albatrosses & $\begin{array}{c}0 \\
(0)\end{array}$ & $\begin{array}{c}4 \\
(0.000)\end{array}$ & $\begin{array}{c}55 \\
(0.003)\end{array}$ & $\begin{array}{c}59 \\
(0.002)\end{array}$ \\
\hline Unidentified petrels & $\begin{array}{c}1 \\
(0.000)\end{array}$ & $\begin{array}{c}11 \\
(0.001)\end{array}$ & $\begin{array}{c}26 \\
(0.001)\end{array}$ & $\begin{array}{c}38 \\
(0.001)\end{array}$ \\
\hline Unidentified birds & $\begin{array}{c}0 \\
(0)\end{array}$ & $\begin{array}{c}0 \\
(0)\end{array}$ & $\begin{array}{c}3 \\
(0.000)\end{array}$ & $\begin{array}{c}3 \\
(0.000)\end{array}$ \\
\hline $\begin{array}{l}\text { Observed fishing effort } \\
\text { (hooks set) }\end{array}$ & $10.5 \times 10^{6}$ & $8.6 \times 10^{6}$ & $17.4 \times 10^{6}$ & $36.6 \times 10^{6}$ \\
\hline
\end{tabular}

bycatch was also higher in the Skate feet compared to the Toothfish fleet $(Z$ $=2.662, \mathrm{p}<0.05)$, although higher in Q1 (i.e. summer) than in other quarters. No variability was observed in the analysis of bycatch occurrence of white-chinned petrels by fleet or quarter (Table 3). When the variability of bycatch rate for all seabirds was analyzed, higher rates were observed in the Kingclip-Toothfish fleet, followed by the Skate and Toothfish fleets $(p<0.001$ for all comparisons; Table 3). This general pattern was observed in bycatch rates for blackbrowed albatrosses and whitechinned petrels, although differences were not significant in the comparison Toothfish versus Skate fleet. Seasonal analysis showed higher bycatch levels for all birds in Q2 (significant differences when comparing Q2 vs. Q3 and Q2 vs. Q4). No differences by quarter were observed in the blackbrowed albatross bycatch rates, but higher bycatch of white-chinned petrels was observed in Q1 and Q2 compared to Q4 (Table 3).

bycatch in the Skate fleet was concentrated in northern Patagonia around and north of $40^{\circ} \mathrm{S}$ (particularly in winter and spring), corresponding with the distribution of the fishing effort (Fig. 3A). However, a wider spatial variability was observed in the Toothfish fleet, with mortalities con-

northern Patagonia (www.minagri.gob.ar/site/pesca/ pesca_maritima/02-desembarques/index.php). This variability was reflected in the captures of the 3 main target species for the fishery (Fig. 2A). Despite the intrinsic variability observed in seabird bycatch rates, observer coverage, and data reliability over the decade (Table 2), the decreasing trend in the fishing effort (in terms of number of vessels as well as number of hooks set) occasioned a substantial decrease (by 1 order of magnitude) in the annual estimates of seabird mortality towards the end of the decade (Fig. 2B).

GLMMs revealed that seabird bycatch was more frequent in the Skate fleet compared to the Toothfish fleet $(Z=2.870, \mathrm{p}<0.01)$, and more frequent in Q3 (i.e. austral winter) compared to Q2 (fall) and Q4 (spring). The occurrence of black-browed albatross centrated in the vicinity of Burwood Bank during spring and summer, but widely distributed to the north along the shelf break between $37^{\circ}$ and $42^{\circ} \mathrm{S}$ during fall and winter (Fig. 3B). Seabird bycatch in the Kingclip-Toothfish fleet was mostly distributed along the central Patagonian shelf between $43^{\circ}$ and $50^{\circ} \mathrm{S}$, with the exception of winter, when low mortality levels were observed in southern Patagonia (Fig. 3C).

\section{DISCUSSION}

The estimated seabird bycatch in the demersal longline fishery (averaging $0.033 \pm 0.019$ birds every 1000 hooks set) showed a strong between-year variability over the decade, ranging from 0.003 to 0.090 

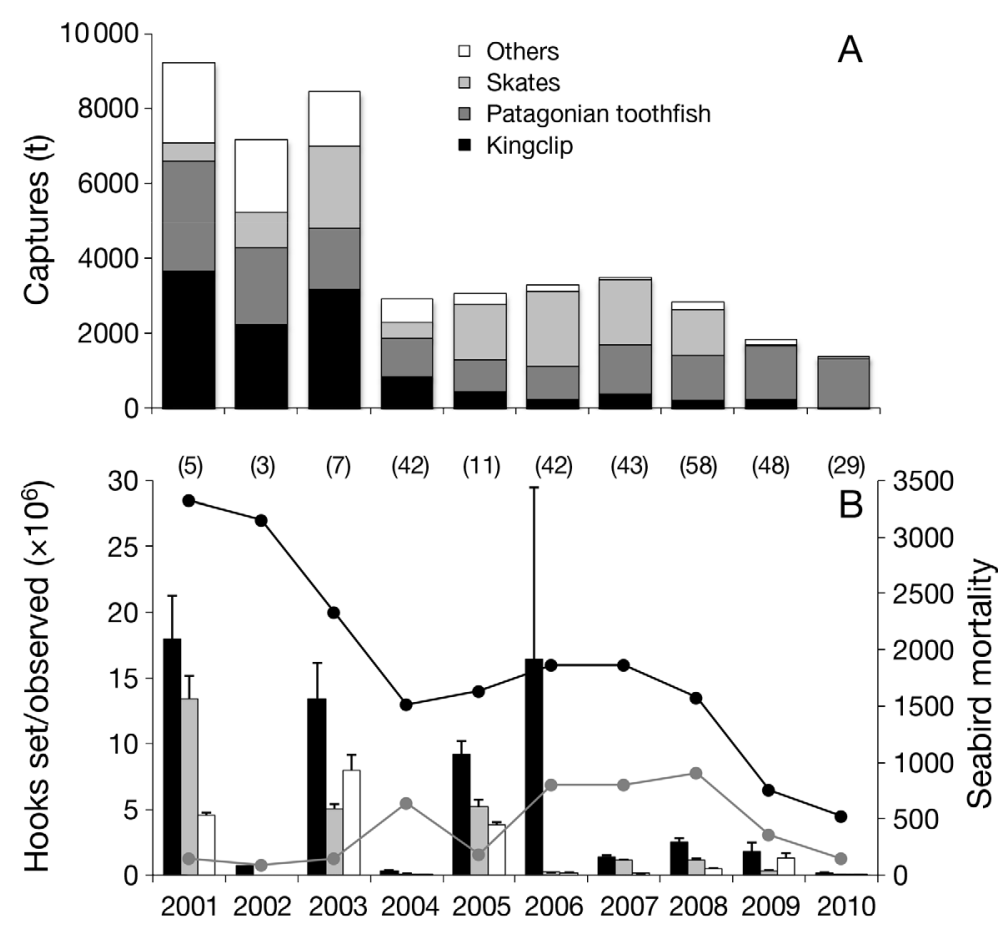

Fig. 2. (A) Fish catches in metric tonnes by main species targeted by Argentinean demersal longline fishery from 2001 to 2010: kingclip Genypterus blacodes, Patagonian toothfish Dissostichus eleginoides, and skates, mainly yellownose skate Dipturus chilensis. Other species include: tadpole codling Salilota australis, banded whiptail Coelorinchus fasciatus, Argentine hake Merluccius hubbsi, rubio Helicolenus lahillei, Argentine seabass Acanthistius brasilianus, and Patagonian grenadier Macruronus magellanicus (data from Argentinean Under-Secretariat of Fisheries database, www.minagri.gob.ar/site/pesca/pesca_maritima/02desembarques/index.php). (B) Total number of hooks set (i.e. fishing effort, black line) and hooks observed for seabird bycatch (i.e. seabird observer coverage, grey line) by year compared with annual mortality estimates for total birds (black bars), black-browed albatross Thalassarche melanophrys (grey bars), and white-chinned petrel Procellaria aequinoctialis (open bars). Percentage of effective seabird observer coverage is shown in parentheses above the graph

birds per 1000 hooks. The overall seabird bycatch rate for the period 2001 to 2010 was lower than that reported for the same fishery during the late 1990s (0.04 birds per 1000 hooks; Favero et al. 2003), although estimates for the first half of the decade were in line with the latter study. From 2006 onwards, mortality levels decreased by 1 order of magnitude. Notwithstanding issues with data reliability (addressed later in this section), the accumulated mortalities estimated in the present study for all seabirds $(7470 \pm 2449)$, black-browed albatrosses (3122 \pm 336), and white-chinned petrels (2180 \pm 233) should be considered conservative, considering that an important percentage of birds caught during the setting operation may not be retrieved when the gear is hauled (Brothers et al. 2010).
While models showed that seabird mortalities were more frequent in the Skate fleet, higher bycatch rates were observed in the Kingclip-Toothfish fleet. This difference was occasioned by the occurrence of more sporadic but important (in terms of number of birds caught) bycatch events in the Kingclip-Toothfish fleet. The large between-year changes in mortality rates and estimated number of birds captured was quite evident during the first half of the decade and can be attributed to the combination of low levels of observer coverage (particularly from 2001 to 2003) and poor data reliability (linked to observers' capacities, limited implementation of seabird protocols, and poor spatio-temporal coverage of observer data). Large mortality estimates for 2006 were mostly driven by an important number of great shearwaters and kelp gulls Larus dominicanus captured by the Skate fleet in a few settings. Data from this fleet in 2006 was also characterized by an important proportion of unidentified albatrosses, most likely black-browed, considering the area of operation of this fleet on the northern Patagonian shelf.

Mortality levels of black-browed albatrosses and white-chinned petrels towards the end of the decade were substantially lower, ranging from a few tens to $<200$ individuals by species. This observed reduction in seabird mortalities cannot be attributed to the decrease of bycatch rates (since there is no clear trend in this regard in any fleet), but to (1) a general drop in fishing effort, (2) the closure in 2008 of the Skate fleet, and (3) the progressive conversion, starting in 2008, of part of the fishing effort in the KingclipToothfish fleet from standard longlines to the use of 'cachaloteras' and pots. The closure of the Skate fleet was particularly relevant, given that this fleet was identified as the one with the highest occurrences of bycatch. Since the area where this fleet operated in northern Patagonia represents a hot spot for the distribution of black-browed albatrosses, particularly during non-breeding season, this closure also reduced the overall overlap between albatrosses and the longline fishery (S. Copello unpubl. data). The changes in the fishing gear used by the Kingclip-Toothfish fleet also decreased the risk posed to seabirds, given that (1) there is no evidence of negative effects of the use 
Table 2. Total fishing effort, observer coverage (reliability in brackets, see 'Materials and methods'), and seabird bycatch by fishing gear and target species (see Table 1 for fleet abbreviations). Observed seabird bycatch, in number of birds and rates, are provided for total birds, black-browed albatross Thalassarche melanophrys (BBA), and white-chinned petrel Procellaria aequinoctialis (WCP). Fishing effort is approximation of number of hooks set. Observed hooks: observed to determine whether they resulted in seabird bycatch (see 'Materials and methods'). Bycatch rates are number of birds bycaught per 1000 hooks set; (-) no data available

\begin{tabular}{|c|c|c|c|c|c|c|}
\hline \multirow[t]{2}{*}{ Year, fleet } & \multirow{2}{*}{$\begin{array}{l}\text { Fishing } \\
\text { effort }\end{array}$} & \multirow{2}{*}{$\begin{array}{c}\text { Observed } \\
\text { hooks }\end{array}$} & \multirow{2}{*}{$\begin{array}{l}\text { Coverage } \\
\text { (reliability) }\end{array}$} & \multicolumn{3}{|c|}{ Observed seabird mortality (bycatch rate) } \\
\hline & & & & Total & BBA & WCP \\
\hline \multicolumn{7}{|l|}{2001} \\
\hline TF & & 0 & & - & - & - \\
\hline KTF & & $0.8 \times 10^{6}$ & & $36(0.045)$ & $28(0.035)$ & $8(0.010)$ \\
\hline $\mathrm{SF}$ & & $0.5 \times 10^{6}$ & & $0(0)$ & $0(0)$ & $0(0)$ \\
\hline Total & $28.5 \times 10^{6}$ & $1.3 \times 10^{6}$ & $4.6 \%$ (poor) & $36(0.028)$ & $28(0.022)$ & $8(0.006)$ \\
\hline \multicolumn{7}{|l|}{2002} \\
\hline $\mathrm{TF}$ & & 0 & & _- & - & _- \\
\hline KTF & & $0.8 \times 10^{6}$ & & $2(0.003)$ & $0(0)$ & $0(0)$ \\
\hline SF & & 0 & & - & - & - \\
\hline Total & $27 \times 10^{6}$ & $0.8 \times 10^{6}$ & $3.0 \%$ (poor) & $2(0.003)$ & $0(0)$ & $0(0)$ \\
\hline \multicolumn{7}{|l|}{2003} \\
\hline $\mathrm{TF}$ & & $1.3 \times 10^{6}$ & & $106(0.080)$ & $40(0.030)$ & $63(0.048)$ \\
\hline KTF & & 0 & & - & - & - \\
\hline $\mathrm{SF}$ & & 0 & & - & - & _- \\
\hline Total & $20 \times 10^{6}$ & $1.3 \times 10^{6}$ & $6.5 \%$ (poor) & $106(0.080)$ & $40(0.030)$ & $63(0.048)$ \\
\hline \multicolumn{7}{|l|}{2004} \\
\hline TF & & $2.0 \times 10^{6}$ & & $0(0)$ & $0(0)$ & $0(0)$ \\
\hline KTF & & $1.1 \times 10^{6}$ & & $3(0.003)$ & $1(0.001)$ & $2(0.002)$ \\
\hline SF & & $2.4 \times 10^{6}$ & & $18(0.008)$ & $6(0.003)$ & $3(0.001)$ \\
\hline Total & $13 \times 10^{6}$ & $5.5 \times 10^{6}$ & $42.3 \%$ (medium) & $21(0.004)$ & $7(0.001)$ & $5(0.001)$ \\
\hline \multicolumn{7}{|l|}{2005} \\
\hline $\mathrm{TF}$ & & $0.6 \times 10^{6}$ & & $0(0)$ & $0(0)$ & $0(0)$ \\
\hline KTF & & $1.0 \times 10^{6}$ & & $147(0.147)$ & $75(0.075)$ & $70(0.070)$ \\
\hline $\mathrm{SF}$ & & 0 & & - & - & - \\
\hline Total & $14 \times 10^{6}$ & $1.6 \times 10^{6}$ & $11.4 \%$ (poor) & $147(0.090)$ & $75(0.046)$ & $70(0.043)$ \\
\hline \multicolumn{7}{|l|}{2006} \\
\hline $\mathrm{TF}$ & & $1.0 \times 10^{6}$ & & $2(0.002)$ & $0(0)$ & $1(0.001)$ \\
\hline KTF & & $0.9 \times 10^{6}$ & & $135(0.150)$ & $1(0.001)$ & $4(0.004)$ \\
\hline $\mathrm{SF}$ & & $4.9 \times 10^{6}$ & & $105(0.021)$ & $13(0.03)$ & $7(0.001)$ \\
\hline Total & $16 \times 10^{6}$ & $6.8 \times 10^{6}$ & $42.5 \%$ (medium) & $242(0.035)$ & $14(0.002)$ & $12(0.002)$ \\
\hline \multicolumn{7}{|l|}{2007} \\
\hline $\mathrm{TF}$ & & $1.4 \times 10^{6}$ & & $1(0.001)$ & $0(0)$ & $0(0)$ \\
\hline KTF & & $0.4 \times 10^{6}$ & & $9(0.023)$ & $9(0.023)$ & $0(0)$ \\
\hline $\mathrm{SF}$ & & $5.2 \times 10^{6}$ & & $30(0.006)$ & $9(0.002)$ & $14(0.003)$ \\
\hline Total & $16 \times 10^{6}$ & $7.0 \times 10^{6}$ & $43.8 \%$ (good) & $40(0.006)$ & $18(0.003)$ & $14(0.002)$ \\
\hline \multicolumn{7}{|l|}{2008} \\
\hline $\mathrm{TF}$ & & $2.0 \times 10^{6}$ & & $5(0.003)$ & $3(0.002)$ & $0(0)$ \\
\hline KTF & & $1.4 \times 10^{6}$ & & $116(0.082)$ & $76(0.054)$ & $24(0.017)$ \\
\hline $\mathrm{SF}$ & & $4.4 \times 10^{6}$ & & $202(0.046)$ & $56(0.013)$ & $47(0.011)$ \\
\hline Total & $13.5 \times 10^{6}$ & $7.8 \times 10^{6}$ & $57.8 \%$ (good) & $323(0.042)$ & $135(0.017)$ & $71(0.009)$ \\
\hline \multicolumn{7}{|l|}{2009} \\
\hline $\mathrm{TF}$ & & $1.8 \times 10^{6}$ & & 3 (0.002) & 1 (0.001) & $0(0)$ \\
\hline $\mathrm{KTF}$ & & $1.3 \times 10^{6}$ & & $265(0.204)$ & $57(0.044)$ & $203(0.156)$ \\
\hline Total & $6.5 \times 10^{6}$ & $3.1 \times 10^{6}$ & $47.7 \%$ (good) & $268(0.086)$ & $58(0.019)$ & $203(0.065)$ \\
\hline \multicolumn{7}{|l|}{2010} \\
\hline $\mathrm{TF}$ & & $0.4 \times 10^{6}$ & & $8(0.020)$ & $2(0.005)$ & $2(0.005)$ \\
\hline KTF & & $0.9 \times 10^{6}$ & & $1(0.001)$ & $0(0)$ & $0(0)$ \\
\hline Total & $4.5 \times 10^{6}$ & $1.3 \times 10^{6}$ & $28.9 \%$ (good) & $9(0.007)$ & $2(0.002)$ & $2(0.002)$ \\
\hline
\end{tabular}

of pots on seabirds, and (2) the mortality rates reported in 'cachaloteras' systems are nil or very low (Moreno et al. 2008, Goetz et al. 2011). However, it should be stressed that the intake by seabirds of fish- ery discards containing hooks from 'cachaloteras' may pose a significant threat to adults and particularly chicks, increasing their mortalities in breeding sites (Phillips et al. 2010). Compared with the Argen- 
Table 3. Paired comparisons from generalized linear mixed models showing the effect of fleet (see Table 1 for fleet abbreviations) and seasonality (by quarters, with Q1 = January to March, and onwards) on bycatch occurrence and rates for all birds, black-browed albatross Thalassarche melanophrys (BBA), and white-chinned petrel Procellaria aequinoctialis (WCP). Models performed using a subset of data from years 2006 to 2010. Sample size for bycatch occurrence models (Z-test) is 7775 longlines set in all cases, and for bycatch rates ( $t$-test) 4369 for all birds, 2434 for BBA, and 1610 sets for WCP. p-values are given in parentheses; values in bold are significant $\left({ }^{* * *} \mathrm{p}<0.001,{ }^{* *} \mathrm{p}<0.01,{ }^{*} \mathrm{p}<0.05\right)$

\begin{tabular}{|c|c|c|c|}
\hline & All birds & BBA & WCP \\
\hline \multicolumn{4}{|c|}{ Bycatch occurrence } \\
\hline TF vs. KTF & 1.268 & 1.226 & 1.004 \\
\hline KTF vs. SF & 1.684 & 1.558 & 0.303 \\
\hline TF vs. SF & $2.870^{* *}$ & $2.662^{*}$ & 1.580 \\
\hline Q1 vs. Q2 & 0.211 & $-2.607^{*}$ & 0.380 \\
\hline Q1 vs. Q3 & 1.551 & -1.216 & 0.152 \\
\hline Q1 vs. Q4 & -1.120 & -1.574 & -0.645 \\
\hline Q2 vs. Q3 & $2.043^{*}$ & 0.855 & 0.631 \\
\hline Q2 vs. Q4 & -1.358 & -0.371 & -0.163 \\
\hline Q3 vs. Q4 & $-2.482^{*}$ & -0.860 & -0.234 \\
\hline \multicolumn{4}{|c|}{ Bycatch rate } \\
\hline TF vs. KTF & $8.965^{* * *}$ & $3.563^{* * *}$ & $5.595^{* * *}$ \\
\hline KTF vs. SF & $-8.983^{* * *}$ & $-4.808^{* * *}$ & $-6.648^{* * *}$ \\
\hline TF vs. SF & $3.724^{* * *}$ & 0.498 & 1.594 \\
\hline Q1 vs. Q2 & 1.893 & -0.015 & -1.883 \\
\hline Q1 vs. Q3 & -0.552 & -0.586 & -1.497 \\
\hline Q1 vs. Q4 & 1.674 & 0.891 & $-4.156^{* * *}$ \\
\hline Q2 vs. Q3 & $-3.330^{* * *}$ & -0.633 & -0.328 \\
\hline Q2 vs. Q4 & $-4.518^{* * *}$ & 1.186 & $-3.081^{* * *}$ \\
\hline Q3 vs. Q4 & 1.421 & 1.206 & -1.805 \\
\hline
\end{tabular}

(Moreno et al. 2006), were in line with the few tens to few hundreds estimated in the present study from the year 2007 onwards, although our estimations for earlier years in the decade were 3- to 7 fold higher. In the southeast Atlantic, mortalities of 20000 birds in 2006 were reported for the demersal longline fisheries targeting hake in Namibia at a rate of 0.14 birds per 1000 hooks (Petersen 2008 as cited in Anderson et al. 2011), while those in South Africa decreased from former estimates of $8000 \pm 6400$ birds in 1994 at a rate of 0.44 birds per 1000 hooks (Barnes et al. 1997) to mortalities ranging from 220 to 245 seabirds per year at a rate of 0.003 birds per 1000 hooks. In this case, the important drop in mortalities was clearly linked to a decrease in bycatch rates moving from 0.033 birds per 1000 hooks in 2000 to 0.001 birds per 1000 hooks in 2006 (Petersen et al. 2009). In both fisheries, the white-chinned petrel was the most important bycatch.

Black-browed albatross accounted for a substantial portion of reported mortalities. A recent study of at-sea distribution of the species showed that at a global scale, the greatest concentrations of

tinean trawl fisheries, there is no question that the combination of significant interaction rates (chiefly seabird collisions with warp cables) with the large fishing effort (hundreds of vessels including coastal ice, offshore ice, and freezer trawlers) lead to seabird mortalities that are at least 1 order of magnitude higher than those estimated in the longline fishery (Favero et al. 2011).

In line with previous studies in the same and neighboring demersal longline fisheries, the blackbrowed albatross and the white-chinned petrel were common species reported in the bycatch. Overall bycatch rate estimations in the present study were higher than those reported for the toothfish fishery operating from Malvinas (Falkland) Islands (0.002 birds per 1000 hooks during 2005-2006; Anderson et al. 2011), although they were close to those from the Chilean artisanal demersal longline targeting toothfish and hake (0.03 to 0.047 birds per 1000 hooks in 2006; Moreno et al. 2006). The annual mortality estimations for these 2 fisheries, 8 to 24 birds killed per year in Malvinas (Anderson et al. 2011) and from a few tens to some 400 seabirds per year in Chile black-browed albatrosses occur in southern South American neritic, shelf-break, and shelf-slope waters (Wakefield et al. 2011). These are highly productive areas that also support large trawl and longline fisheries, known to take substantial numbers of seabirds (Croxall \& Wood 2002, Sullivan et al. 2006, Arata et al. 2009, Favero et al. 2011), which may be unsustainable for these populations in the long term. Although the black-browed albatross is among the most abundant albatross species, with a current global population of over 600000 breeding pairs (ACAP 2010a), increased incidental mortality since the mid-1980s in longline and trawl fisheries has caused widespread and unsustainable population declines (Tuck et al. 2011) and the further deterioration of its conservation status, currently listed as Endangered (IUCN 2011). Black-browed albatrosses breeding in the Malvinas (Falkland) Islands extensively use the Patagonian shelf, both during the breeding season and the nonbreeding season. They have been reported to show an at-sea spatial segregation during the post-guard period (January to March), with individuals breeding to the west of the archipelago travelling chiefly to the 

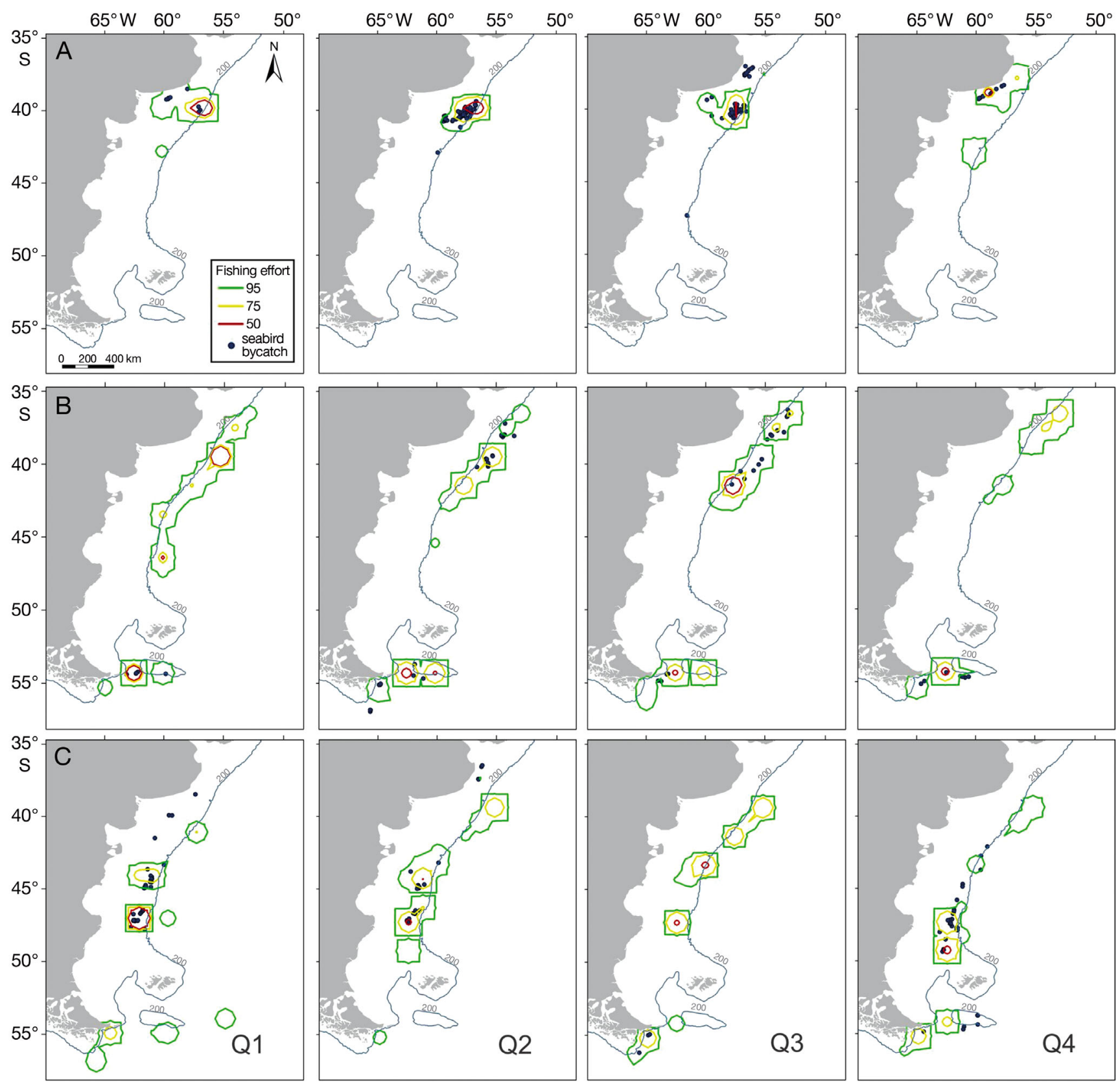

Fig. 3. Locations of observed seabird bycatch in the demersal longline fleet $(\bullet)$ superimposed with the kernel analysis $(50 \%$, $75 \%$, and $95 \%$ contour plots) of the distribution of fishing effort by fleet and quarter (with Q1 = January to March, and onwards). (A) Skate fleet, vessels targeting skate Dipturus chilensis with Spanish system, (B) Toothfish fleet, targeting Patagonian toothfish Dissostichus eleginoides with autoline gear, and (C) Kingclip-Toothfish fleet, targeting Patagonian toothfish and kingclip Genypterus blacodes with Spanish or autoline systems

north, and those breeding in the south of the archipelago travelling to the south/southwest of the islands (Huin 2002). A preliminary overlap of these distributions with the observed fishing effort and bycatch (see Q1 distributions in Fig. 3) suggest that the former group could be primarily affected by the Kingclip-Toothfish fleet while the latter could be mostly affected by the Toothfish fleet. Hence, a stronger impact by fisheries on western colonies could be hypothesized on the basis of the higher levels of bycatch observed in the Kingclip-Toothfish fleet. These matters will be a matter of further investigation.

The white-chinned petrel, widely distributed in the southern hemisphere and currently listed as Vulner- 
able (IUCN 2011), was the other species frequently reported in the bycatch. According to the species' year-round distribution (Phillips et al. 2006), and considering that in the region its most important breeding site is South Georgia (ca. 770000 breeding pairs vs. only few tens breeding in the Malvinas [Falklands] Islands; ACAP 2010b), it is very likely that the vast majority of individuals killed by demersal longliners come from the main breeding grounds. Other species of concern showing declines in South Georgia populations, such as the wandering albatross, overlapped distributions with the Argentinean demersal longliners. Although this fishery has been referred to as a contributor to continued declines (Tuck et al. 2003), the low levels of incidental mortality recorded throughout the decade strongly suggest that the Argentinean demersal longline fishery poses a minor threat to this species. This species has been reported to interact with pelagic longline vessels operating in neighboring waters, such as the midwater longline fleet targeting tuna and swordfish from Uruguay (Jiménez et al. 2009, 2012) and vessels operating in international waters under the administration of the International Convention for the Conservation of Atlantic Tuna (Tuck et al. 2011). This is true as well for other large albatrosses (Diomedea spp.) that visit the Patagonian Shelf from distant breeding sites but were not observed in the bycatch of Argentinean demersal longliners.

Since 2001, and after the publication of the Federal Fisheries Council Resolution 03/01 calling for the estimation of seabird bycatch in longline fisheries (tasked to the National Fisheries Institute and National Universities), training programs aimed at fishery observers were implemented in collaboration with other relevant stakeholders in order to improve the quality of seabird data obtained by the Argentinean National Observers Program. Although such initiatives (including the developments of specific seabird protocols for longline and trawl fisheries) were progressively refined over the decade and particularly after the accession of Argentina to the ACAP in 2006, the system to collect, store, and process bycatch data still needs to be fully implemented. Progress in Argentina was achieved with the cooperation of different stakeholders, including the government (Under-Secretariat of Fisheries, Ministry of Environment, Federal Fisheries Council, National Fisheries Institute), scientists (National Research Council, National Universities), and NGOs (Aves Argentinas, Fundación Vida Silvestre Argentina, BirdLife International Albatross Task Force). However, there are critical actions yet to be implemented or finalized to reassure that bycatch levels in longline fisheries (but also trawl fisheries) are reduced to negligible levels. To that end, it is essential that the authorities ensure not only the introduction of but also effective compliance with the conservation measure calling for the use of mitigation in demersal longline vessels (Federal Fisheries Council Resolution 08/08 entered into force in 2010) is urgent, along with the monitoring of the Argentinean NPOA-S adopted in 2010. In addition, there is a need to (1) further increase the capacities within the National Observer Program; (2) improve the coverage in the implementation of seabird protocols, including gathering of data on seabird interactions, bycatch, and mitigation; (3) continue work on the introduction of an ecosystem approach among decision-makers; and (4) create the mechanisms to engage with the fishing industry in order to improve conditions for the gathering of data and deployment of mitigation methods.

A recent review of the NPOA-S conducted in 2012 indicated that the use of bird-scaring lines was implemented by some of the longline fisheries in 2011, and that ca. $50 \%$ of line settings in the same year occurred during the night. There is no information on line-weighting regimes used by the fleet. As a consequence of this first implementation report, the Federal Fisheries Council highlighted the need to improve mechanisms to ensure compliance of the conservation measure. The present study indicates that special attention should be paid to differences observed among fishing fleets and seasonal variability in order to prioritize conservation actions where or when negative impacts are stronger.

Acknowledgements. This study was financially supported by grants from the National Agency for the Promotion of Science and Technology (Agencia Nacional de Promoción Científica y Tecnológica, PICT 2008-0590), the National Research Council (PIP CONICET 00070), and the National University of Mar del Plata (Argentina). We particularly thank Phillip and Marsha Dowd, as well as observers from the National Observers Program (INIDEP).

\section{LITERATURE CITED}

ACAP (Agreement on the Conservation of Albatrosses and Petrels) (2010a) ACAP species assessment: black-browed albatross Thalassarche melanophrys. www.acap.aq/ acap-species/download-document/1183-black-browedalbatross (accessed May 2012)

ACAP (Agreement on the Conservation of Albatrosses and Petrels) (2010b) ACAP species assessment: whitechinned petrel Procellaria aequinoctialis. www.acap.aq/ acap-species/download-document/1178-white-chinnedpetrel (accessed May 2012) 
ACAP (Agreement on the Conservation of Albatrosses and Petrels) (2011) Report of the Sixth Meeting of the Advisory Committee. Annex 18: Demersal longline mitigation summary advice. Summary advice statement for reducing impact of demersal longlines on seabirds. www.acap. aq/meeting-documents/download-document/1842-ac6report (accessed May 2012)

ACAP (Agreement on the Conservation of Albatrosses and Petrels) (2012) Agreement Annex 1. www.acap.aq/ instruments/download-document/1191-acap-agreement (accessed May 2012)

Anderson ORJ, Small CJ, Croxall JP, Dunn EK, Sullivan BJ, Yates O, Black A (2011) Global seabird bycatch in longline fisheries. Endang Species Res 14:91-106

Arata J, Croxall JP, Huin N, Nicholls D and others (2009) Parte 2. Albatros. In: Falabella V, Campagna C, Croxall J (eds) Atlas del Mar Patagonico: especies y espacios. Proyecto Modelo del Mar, Argentina, WCS, CONICET, and BirdLife International, Buenos Aures, p 45-97

Arnold JM, Brault S, Croxall JP (2006) Albatross populations in peril? A population trajectory for black-browed albatrosses at South Georgia. Ecol Appl 16:419-432

Barnes KN, Ryan PG, Baix-Hinzen Ch (1997) The impact of the hake Merluccius spp. longline fishery off South Africa on procellariiform seabirds. Biol Conserv 82: 227-234

Bastida R, Rodriguez D, Scarlatto N, Favero M (2005) Marine biodiversity of the South-Western Atlantic Ocean and main environmental problems of the region. In: Miyazaki N, Adeel Z, Ohwada K (eds) Mankind and the oceans. United Nations University Press, New York, NY, p 172-207

$>$ Brothers N (1991) Albatross mortality and associated bait loss in the Japanese longline fishery in the Southern Ocean. Biol Conserv 55:255-268

Brothers N, Duckworth AR, Safina C, Gilman EL (2010) Seabird bycatch in pelagic longline fisheries is grossly underestimated when using only haul data. PLoS ONE 5: e12491

Consejo Federal Pesquero (2010) Resolution CFP 15-10 (Annex): Plan de Acción Nacional para reducir la interacción de aves con pesquerías en la República Argentina. www.minagri.gob.ar/site/pesca/pesca_maritima/01= plan $\% 20$ de $\% 20$ accion $\% 20$ nacional/03-PAN-AVES/index. php

Crawley MJ (2007) The R book. John Wiley \& Sons, New York, NY

> Croxall JP, Wood AG (2002) The importance of the Patagonian Shelf for top predator species breeding at South Georgia. Aquat Conserv Mar Freshw Ecosyst 12:101-118

Croxall JP, Butchart SHM, Lascelles B, Stattersfield AJ, Sullivan B, Symes A, Taylor P (2012) Seabird conservation status, threats and priority actions: a global assessment. Bird Conserv Int 22:1-34

FAO (Food and Agriculture Organization of the United Nations) (2008) Report of the expert consultation on best practice technical guidelines for IPOA/NPOA-seabirds. FAO Fish Aquacult Rep No. 880, Bergen, Norway, 2-5 Sep 2008

Favero M, Silva MP (2005) Estado actual y conservación de aves pelágicas que utilizan la plataforma continental Argentina como área de forrajeo. Hornero 20:95-110

Favero M, Khatchikian C, Arias A, Silva MP, Cañete G, Mariano-Jelicich R (2003) Estimates of seabird bycatch along the Patagonian Shelf by Argentine longline fishing ves- sels, 1999-2001. Bird Conserv Int 13:273-281

Favero M, Blanco G, García G, Copello S and others (2011) Seabird mortality associated with ice trawlers in the Patagonian shelf: effect of discards on the occurrence of interactions with fishing gear. Anim Conserv 14:131-139

Gales R (2008) Flagship species at half mast. In: De Roy T, Jones M, Fitter J (eds) Albatross. Their world, their ways. David Bateman, Auckland, p 148-151

Gandini PA, Frere E (2006) Spatial and temporal patterns in the bycatch of seabirds in the Argentinean longline fishery. Fish Bull 104:482-485

Goetz S, Laporta M, Martinez Portela J, Begoña Santos M, Pierce GJ (2011) Experimental fishing with an 'umbrellaand-stones' system to reduce interactions of sperm whales (Physeter macrocephalus) and seabirds with bottom-set longlines for Patagonian toothfish (Dissostichus eleginoides) in the Southwest Atlantic. ICES J Mar Sci 68:228-238

Gómez Laich A, Favero M (2007) Spatio-temporal variability in mortality rates of white-chinned petrels Procellaria aequinoctialis interacting with longliners fishing in the South-west Atlantic. Bird Conserv Int 17:359-366

Gómez Laich A, Favero M, Mariano-Jelicich R, Blanco G and others (2006) Environmental and operational variability affecting the mortality of black-browed albatrosses associated to long-liners in Argentina. Emu 106: $21-28$

> Huin N (2002) Foraging distribution of the black-browed albatross, Thalassarche melanophris, breeding in the Falkland Islands. Aquat Conserv Mar Freshw Ecosyst 12: 89-99

IUCN (2011) IUCN Red List of Threatened Species, version 2011.2. www.iucnredlist.org (accessed 28 Feb 2012)

Jiménez S, Domingo A, Brazeiro A (2009) Seabird bycatch in the Southwest Atlantic: interaction with the Uruguayan pelagic longline fishery. Polar Biol 32:187-196

Jiménez S, Domingo A, Abreu M, Brazeiro A (2012) Risk assessment and relative impact of Uruguayan pelagic longliners on seabirds. Aquat Living Resour 25:281-295

Klaer N, Polacheck T (1997) bycatch of albatrosses and other seabirds by Japanese longline fishing vessels in the Australian fishing zone from April 1992 to March 1995. Emu 97:150-167

Louzao M, Arcos JM, Guijarro B, Valls M, Oro D (2011) Seabird-trawling interactions: factors affecting species-specific to regional community utilisation of fisheries waste. Fish Oceanogr 20:263-277

Melvin EF, Parrish JK (2001) Seabird bycatch: trends roadblocks and solutions. University of Alaska Sea Grant, AK-SG-01-01, Fairbanks, AK

> Moreno CA, Arata JA, Rubilar P, Hucke-Gaete M, Robertson G (2006) Artisanal longline fisheries in southern Chile: lessons to be learned to avoid incidental seabird mortality. Biol Conserv 127:27-36

Moreno CA, Castro R, Mujica LJ, Reyes P (2008) Significant conservation benefits obtained from the use of a new fishing gear in the Chilean Patagonian toothfish fishery. CCAMLR Sci 15:79-91

Myers RA, Pepin P (1990) The robustness of lognormal based estimators of abundance. Biometrics 46:1185-1192

> Pennington M (1983) Efficient estimators of abundance for fish and plankton surveys. Biometrics 39:281-286

> Petersen SL, Honig MB, Ryan PG, Underhill LG, Goren M (2009) Seabird bycatch in the demersal longline fishery off southern Africa. Afr J Mar Sci 31:205-214 
Phillips RA, Silk JRD, Croxall JP, Afanasyev V (2006) Yearround distribution of white-chinned petrels from South Georgia: relationships with oceanography and fisheries. Biol Conserv 129:336-347

Phillips RA, Ridley C, Reid K, Pugh PJA, Tuck GN, Harrison N (2010) Ingestion of fishing gear and entanglements of seabirds: monitoring and implications for management. Biol Conserv 143:501-512

Pinheiro JC, Bates DM (2000) Mixed-effects models in S and S-PLUS. Springer, Berlin

R Development Core Team (2011) R: a language and environment for statistical computing. R Foundation for Statistical Computing, Vienna. www.R-project.org

Rivalan P, Barbraud C, Inchausti P, Weimerskirch H (2010) Combined impacts of longline fisheries and climate on the persistence of the Amsterdam albatross Diomedea amsterdamensis. Ibis 152:6-18

Robertson G (2000) Effect of line sink rate on albatross mortality in the Patagonian toothfish longline fishery. CCAMLR Sci 7:133-150

Robertson G, Gales R (1998) Albatross biology and conservation. Surrey Beatty \& Sons, Baukham Hills

Seco Pon JP, Gandini P, Favero M (2007) Effect of longline configuration on the seabird mortality in the Argentine semi-pelagic Kingclip Genypterus blacodes fishery. Fish Res 85:101-105

Sullivan BJ, Reid TA, Bugoni L (2006) Seabird mortality on factory trawlers in the Falkland Islands and beyond. Biol Conserv 131:495-504

Editorial responsibility: Rebecca Lewison, San Diego, California, USA
Tuck GN, Polacheck T, Bulman CM (2003) Spatio-temporal trends of longline fishing effort in the Southern Ocean and implications for seabird bycatch. Biol Conserv 114: $1-27$

Tuck GN, Phillips RA, Small C, Thomson RB and others (2011) An assessment of seabird-fishery interactions in the Atlantic Ocean. J Mar Sci 68:1628-1637

> Wakefield ED, Phillips RA, Trathan PN, Arata J and others (2011) Habitat preference, accessibility, and competition limit the global distribution of breeding Black-browed Albatrosses. Ecol Monogr 81:141-167

> Watkins BP, Petersen SL, Ryan PG (2008) Interactions between seabirds and deep-water hake trawl gear: an assessment of impacts in South African waters. Anim Conserv 11:247-254

Weimerskirch H, Jouventin P (1987) Population dynamics of the wandering albatross, Diomedea exulans, of the Crozet Islands: causes and consequences of the population decline. Oikos 49:315-322

> Weimerskirch H, Capdeville D, Duhamel G (2000) Factors affecting the number and mortality of seabirds attending trawlers and long-liners in the Kerguelen area. Polar Biol 23:236-249

Worton BJ (1989) Kernel methods for estimating the utilization distribution in home-range studies. Ecology 70 : 164-168

Zuur AF, Ieno EN, Walker NJ, Saveliev AA, Smith GM (2009) Mixed effects models and extensions in ecology with R. Springer, New York, NY

Submitted: June 6, 2012; Accepted: November 14, 2012 Proofs received from author(s): January 20, 2013 